\title{
Study of Micromycoflora and Fungal Diversity Analysis and Comparison among Three Different Ecosystems (Agricultural Land, Barren and Garden Land) of Khardah Municipality, 24 Parganas (N), West Bengal, India
}

\author{
Swapan Kumar Ghosh ${ }^{1^{*}}$ and P.K. Sur ${ }^{2}$ \\ ${ }^{1}$ Molecular Mycopathology Laboratory, Biocontrol and Cancer Research Unit, Ramakrishna \\ Mission Vivekananda Centenary College (Autonomous), Rahara, Kolkata -700118, W.B., India \\ ${ }^{2}$ A-9 /45, Kalyani-741235, Nadia, W.B., India \\ *Corresponding author
}

Ke y w o r d s
Soil,
Micromycoflora,
Simpson index,
Fungal diversity.
Article Info
Accepted:
$\begin{aligned} & 14 \text { July } 2017 \\ & \text { Available Online: } \\ & \text { 10 September } 2017\end{aligned}$

\section{A B S T R A C T}

Soil microflora and their diversity study are now modern trends to know the proper soil health. Greater diversity of fungi in soil indicates better health of soil. In this experiment agricultural soil, barren land and garden soil were taken for their micromycoflora study and the diversity of microfungi were analysed by Simpson index and compared among the three types of soil. Total 563 colonies were isolated from the 38 soil samples collected from three different ecosystem types. Sixty eight (68) different species belonging to 31 genera were recorded. Maximum variation was observed in the agriculture soil, 350 colonies were isolated from 20 samples having 67 species and 31 genera. In all 54 species belonging to 28 genera were isolated from barren land samples. In the Garden soil samples, there were 123 colonies belonging to 30 genera and 66 species. Three genera (Candida, Debaryomyces and Rhodotorula) of yeasts were isolated and identified in three types of soil of this municipality and adjoining area. The study reveals that $T$. viride exists in maximum per cent of occurrence. It is a good indication of that as $T$. viride is natural biocontrol agent against many plant pathogens. Aspergillus was dominant in all the three types of soils followed by, Trichoderma, Fusarium, Alternaria, Penicillium and Gloeosporium. Aspergillus has 9 species, Penicillium has 6 species, Curvularia has 5 species. The diversity Simpson index (0.6139) is found in agriculture soil in comparison to barren (0.9763) and garden (0.950) soil. It means maximum diversity of fungi exists in the agriculture soil. Fungi get maximum and varied nutrient from agriculture soil. So agriculture soil supports maximum diversity of fungi.

\section{Introduction}

We are very much dependent on the soil for its needs in agriculture as the soil is the universal media for all kinds of crops and, of late, contributing to our energy supply with crops grown primarily for biofuels. Actually soil is a basic building block for life on earth. Soil is a dynamic and multifunctional system that exists as thin layer on the Earth's crust. Sanchez and Swaminathan (2005) linked among the hunger, unhealthy people and unhealthy soils in Africa. The various combinations of soil forming factors have given rise to an exceptional diversity of soil types across the world. The kingdom Fungi is 
one of the most diverse groups of organisms on Earth, and they are integral ecosystem agents that govern soil carbon cycling, plant nutrition, and pathology. Fungi are widely distributed in all terrestrial ecosystems, but the distribution of species, phyla, and functional groups has been poorly documented. On the basis of 365 global soil samples from natural ecosystems, Tedersoo et al., (2014) determined the main drivers and biogeographic patterns of fungal diversity and community composition.

The properties of soils and associated environmental conditions govern the various ecosystem functions of soil such as decomposition and transformation of organic wastes, mediating nutrient cycles, and influencing populations of soil organisms such as bacteria and fungi. Recently scientists gave the attention on 'fertility' or 'quality' and more recently 'soil health'. The soil fungi occupied a very important position i.e., decomposer of ecosystem. Their vital function with other microbes is the decomposition of organic matter and the release of the nutrients locked up in plants and animals, bringing about the recycling of nutrients.

There are near about 75,000 species of soil fungi are recorded in the world (Finlay 2007), and the soil formulation, soil fertility, and crop protection largely depend on microbial community (Schimel et al., 2005). The diversity of soil fungi depends on the types of soils and organic matters and water holding capacity, $\mathrm{pH}$, temperature and after all rhizosphere of soil.

Continuous urbanization on natural fields causes depletion of diversity of fungi and other microbes of soil and rhizosphere are changing. Biocontrol agents for control of crops from many plant diseases, antibiotic (Penicillin, Griseofulvin, etc) producing fungi and other industrial important fungi are habited in soil; moreover soil borne plant pathogens exist in soil. With the advent of chemical fertilizers and pesticides /fungicides, it was thought that a permanent and reliable solution of soil fertility and crop pathogens have been achieved but it has been proved that chemical fertilizers and pesticide application are not safe to the environment as the toxicants cause environmental pollution and have harmful effects on human beings (PAN, 2007). Chemical fertilizers may have harmful effects on the soil and its life, especially when they are very concentrated and water soluble (Smith et al., 2008). Ammonium sulphate is a very strong biocide, hindering nitrogen fixation and killing nematodes and earthworms. Superphosphate has a negative effect on free-living nitrogenfixing bacteria (Primavesi and Primavesi, 1990). Nitrate levels above $10 \mathrm{mg} / \mathrm{L}$ (10 ppm) in groundwater can cause 'blue baby syndrome' (acquired methemoglobinemia), leading to hypoxia (which can lead to coma and death if not treated) (Ward et al., 2005; Powler, 2006). Unfortunately to gain a target crop production with chemical fertilizers and pesticides, over 100 species of non target organisms are adversely affected (Alabouvette and Couteadier, 1992). Despite realization of adverse effects of chemical fertilizers and pesticides on plants, animals and environment, they are being applied indiscriminately (Eckert and Ogawa, 1988; PAN, 2007). So, we are constantly in taking these poisonous chemicals.

Keeping environment pollution and human health hazards in mind, we have tried to evaluate the soil fungal diversity in suburban municipality- Khardah, for indicating changes of soil health. The objective of this study includes to record the soil microflora of agricultural land, barren and garden land and fungal diversity comparison among the tree ecosystems of Khardah Municipality. 


\section{Materials and Methods}

\section{Study area}

Khardah Municipality (Fig. 1) was taken as model study for fungal diversity. This is situated at Barrakpore subdivision of 24Parganas (N) of West Bengal, India. It is surrounded in West by Holy Ganga (Hooghly River), North by Titaghar Municipality, South by Panihati Municipality and East by some Panchayat areas and then Barasat Municipalities. It's out skirts all around are agrifields of some vegetables, rice and some barren lands. Within the town ship of municipality there are some play grounds, public gardens, municipality gardens, parks, ponds and other natural's undisturbed fields and some small - large industries are also present.

The 24-Parganas $(\mathrm{N})$ district of West Bengal is situated in the tropical zone and extends from latitude $22^{\circ} 11^{\prime} 6^{\prime \prime}$ North to $23^{\circ} 15^{\prime} 2^{\prime \prime}$ North and from longitude $88^{\circ} 20^{\prime}$ East to $89^{\circ} 05^{\prime}$ East.It is bordered to Nadia by North, to Bangladesh (Kulna Division by North and east), to south 24 -Parganas and Kolkata by south and to Kolkata, Howrah and Hooghly by West. The elevation of the district is $2,134 \mathrm{~m}$ (7001ft). It lies within the GangaBrahmaputra delta.

Annual rainfall is $1579 \mathrm{~mm}$. The weather remains humid and dry during the most time of the year except the rainy seasons. It remains dry during the winter (mid-November to mid-February) and humid during summer. Temperature remains $41^{\circ} \mathrm{C}$ (maximum) in May and $10^{\circ} \mathrm{C}$ (minimum) in January. Relative humidity remains between $50 \%$ in March and $90 \%$ in July (http://famillpedia.wikia.com/wiki/north_24_ pargana_district\#climate; State of Forest Report 2003).

\section{Collection of soil sample}

Twenty (20) different soil samples were collected from different agricultural field (Brinjal, Tomato, Rice) and 9 samples were collected from nine different barren lands and also 9 soil samples were collected from 9 different garden lands.

Agricultural and barren lands were selected on all the directions along the outskirt of the city of Khardah but the gardens were situated in the city.

Agricultural soils were collected from rhizosphere of selected crops, barren \& garden soils from 10-15 inch dept after discarding surface soil.

Preparation of the soil for isolation of fungi and Isolation and identification of fungi and fungal diversity index

\section{Preparation of the soil for isolation of fungi}

Collected soils were spread in dark and air dried. The dried soils are powdered and sieved under $1.0 \mathrm{~mm}$ mesh.

The powder sieved soil weight to $1 \mathrm{gm}$ and they are used for soil microbes isolation, and they are preserved in $4^{0} \mathrm{C}$ temperature for further used also.

\section{Isolation of fungi}

\section{Dilution plate method}

Isolation of fungi from the soil samples were carried out by dilution plate method (Dhingra and Sinclair 1985; Warcup, 1950) using different synthetic and semi synthetic media.

Generally, isolation was done in potatodextrose agar (PDA) medium at $28 \pm 2{ }^{\circ} \mathrm{C}$ following the methodology 
recommended by Dhingra and Sinclair (1985). Rose Bengal agar medium (modified from Tsao, 1964) was used for the soil dilution method.

Other media such as potato carrot agar medium, Czapek Dox agar medium (Dox, 1910), and malt extract agar medium were also used.

\section{Identification of fungi}

The fungi were identified with the help of literature (Nagamani et al., 2002; Barnett, 1998; Ellis, 1993; Gilman, 2001; Raper and Fennel, 1965; Thom and Raper, 1941; Subramanian, 1971, 2007).

\section{Fungal diversity index}

The number of soil sample taken, the number of fungal colony isolated, number of colony of individual fungus were recorded from three types of soils -agriculture, barren and garden. Their fungal diversity indices were calculated by Simpsons Diversity index (D): is a simple mathematical measure that characterizes species diversity in a community. It is calculated using the following formula.

\section{Simpson's index}

$$
D=1-\left[\sum n i(n i-1) /[\mathrm{N}(\mathrm{N}-1)]\right.
$$

Where,

$\mathrm{n}=$ No. of individuals in each species.

$\mathrm{N}=$ Total no. of individuals.

The $\mathrm{D}$ assumes value between $0 \& 1 . \mathrm{D}=0$ indicates maximum diversity while

$\mathrm{D}=1$ represents the least diversity (Harrison et al., 2004, http://en wiki pedia.org/ wiki/ Diversity- index)
Isolation, characterization and identification of yeasts

\section{Isolation}

Collected soils were spread in dark and air dried. The dried soils are powdered and sieved under sixty mess. The powder sieved soil weight to $1 \mathrm{gm}$ and they are used for soil microbes isolation, and they are preserved in $4^{0} \mathrm{C}$ temperature for further used also. Isolation of yeast from the soil samples were carried out by dilution plate method (Warcup, 1950) using MA medium. The petri dishes were incubated at $25^{\circ} \mathrm{C}$ for 3 days.

Single cell isolate of each type of yeasts was obtained by streaking loopful of cells on MA medium and transferring well isolated colonies to MA. The isolates were maintained on Malt-yeast-Glucose-Peptone -Agar medium of Wickerham et al., (1951) at $28^{\circ} \mathrm{C}$ with monthly subculturing.

\section{Identification}

Identification of each isolate of yeast up to species level was carried on the basis of standard morphological, and physiological, biochemical tests presented by Barnett et al., (2000), Kurtzman and Fell (2006), and Rose and Harisson (1987-1993).

Morphological and Microscopical investigation - The colonies were observed and described on MA and MYGPA medium. The isolates were also grown in MA and MYPGA broth for determination of their cultural characteristics (pellicle, sedimentation or ring formation). In certain cases, the isolates were grown on sterile slices of carrot for induction of ascospore formation.

Physiological or biochemical tests- For carbon and nitrogen assimilation, the basal medium of Barnetts et al., (2000) was used. 
The results were determined after the 3 th, $7^{\text {th }}$, $14^{\text {th }}, 21$ th and $28^{\text {th }}$ day.

The ability of some carbohydrates for anaerobic assimilation (fermentation) was determined by using Durhan glass tubes after 3 weeks. The quantity of the tested carbohydrates was $2 \%$.

For Diazonium blue -B (DBB) test, a ten day old culture on MYPG was held at $55^{\circ} \mathrm{C}$ for three hours and then flooded with ice- cold DBB reagent. The reagent was prepared by dissolving diazonium blue salt (Sigma) in cold $0.5 \mathrm{M}$-tris-HCL buffer $\mathrm{pH} 7.0$ at $1 \mathrm{mg} / \mathrm{ml}$ the reagent was kept ice - cold and used within few minutes of pre parathion. Other additional tests such as starch formation, urea hydrolysis, cycloheximide $(0.01 \%$ or $0.1 \%)$, were performed.

The isolated yeasts were stored by freezedrying with protecting medium (sucrose $10 \%$, gelatine $1.5 \%$ and agar $0.1 \%$ ).

\section{Results and Discussion}

\section{Diversity of soil fungi including yeasts from Khardah Municipality}

The data in table 1 showed that total 563 colonies were isolated from the 38 soil samples collected from three different ecosystem types, namely agriculture field, barren land and garden soil. The colonies are distributed in 68 different species belonging to 31 genera. Maximum variation was observed in the agriculture soil, 350 colonies were isolated from 20 samples having 67 species and 31 genera. In all 54 species belonging to 28 genera were isolated from barren land samples. In the Garden soil samples, there were 123 colonies belonging to 30 genera and 66 species. Three genera (Candida, Debaryomyces and Rhodotorula) of yeasts were isolated and identified in three types of soil (Agricultural, barren and garden soil) of this municipality and adjoining area. Mustaq et al., (2004) similarly studied soil yeasts from Pakistan. The study reveals that $T$. viride exists in maximum per cent of occurrence. It is a good indication of that as $T$. viride is natural biocontrol agents against many plant pathogens (Alabouvette and Couteadier, 1992). The dominant genera in all the ecosystem types were also studied. Aspergillus was dominant in all the three types of soils followed by Trichoderma, Fusarium, Alternaria, Penicillium, and Gloeosporium. Aspergillus has 9 species, Penicillium has 6 species, Curvularia has 5 species. Kumar et al., (2015) found that Aspergillus is dominant in different Populated Area of Bareilly City.

Table 2 indicated that least diversity Simpson index (0.6139) is found in agriculture soil in comparison to barren (0.9763) and garden (0.950) soil. It means maximum diversity of fungi exists in the agriculture soil. Fungi get maximum and varied nutrient from agriculture soil. So agriculture soil supports maximum diversity of fungi. The diversity index of both garden and barren soil is near to 1. It indicates diversity of fungi in both garden and barren soil is poor. It may be due to lack of rhizosphere zone. This result was supported by other authors (Wahegaonkar, et al., 2011). They showed the diversity of soil fungi in Aurangabad, M.S. India. They collected 23 soil samples of three eco-systems (agriculture, garden and barren lands) in and around the city of Aurangabad. Total 45 genera distributed in 85 species were isolated and identified. They reported maximum genera of fungi in agriculture soil. Their isolated dominant genera in all soil types were Aspergillus, Alternaria, Trichoderma etc. Similarly Saravanakumar and Kaviyarasan (2010) collected 48 soil sample from wet evergreen forest of Tamilnadu, South India and isolated a total of 76 taxa belonging to 25 genera. They also analysed the fungal diversity index of forest soil. 
Table.1 Isolated fungi and their number of colony, $\%$ of occurrence in the agriculture, barren land and Garden soil

\begin{tabular}{|c|c|c|c|c|c|c|c|c|c|c|c|}
\hline \multirow{3}{*}{$\begin{array}{l}\text { S. } \\
\text { No } \\
\text {. }\end{array}$} & \multirow{3}{*}{$\begin{array}{l}\text { Fungal } \\
\text { species }\end{array}$} & \multicolumn{6}{|c|}{ Agriculture Soil } & \multirow{2}{*}{\multicolumn{2}{|c|}{ Barren land soil }} & \multirow{2}{*}{\multicolumn{2}{|c|}{ Garden Soil }} \\
\hline & & \multicolumn{2}{|c|}{ Brinjal } & \multicolumn{2}{|c|}{ Tomato } & \multicolumn{2}{|l|}{ Rice } & & & & \\
\hline & & \begin{tabular}{|l|}
$\begin{array}{l}\text { No.of } \\
\text { colony }\end{array}$ \\
\end{tabular} & $\begin{array}{l}\text { Occurrenc } \\
\text { e }\end{array}$ & $\begin{array}{l}\text { No.of } \\
\text { Colony }\end{array}$ & $\begin{array}{c}\text { Occurren } \\
\text { ce }\end{array}$ & $\begin{array}{l}\text { No. } \\
\text { of } \\
\text { colon } \\
y\end{array}$ & Occurrence & $\begin{array}{l}\text { No.of } \\
\text { colony }\end{array}$ & Occurrence & $\begin{array}{l}\text { No.of } \\
\text { colony }\end{array}$ & $\begin{array}{l}\text { Occurrenc } \\
\text { e }\end{array}$ \\
\hline 1. & $\begin{array}{l}\text { Alternaria } \\
\text { alternata }\end{array}$ & 5 & 4.16 & 3 & 2.41 & 4 & 3.77 & 2 & 2.29 & 4 & 2.0 \\
\hline 2. & $\begin{array}{l}\text { Alternaria } \\
\text { tenuissima }\end{array}$ & 3 & 2.5 & 3 & 2.41 & 2 & 1.88 & 2 & 2.29 & 3 & 1.5 \\
\hline 3. & $\begin{array}{l}\text { Acremonium } \\
\text { stomaticum }\end{array}$ & 3 & 2.5 & 2 & 1.61 & 1 & \begin{tabular}{|l|}
0.94 \\
\end{tabular} & 0 & 0.00 & 4 & 2.0 \\
\hline 4. & $\begin{array}{l}\text { Aspergillus } \\
\text { niger }\end{array}$ & 3 & 2.5 & 4 & 3.22 & 4 & 3.77 & 1 & 1.14 & 4 & 2.0 \\
\hline 5. & A. flavus & 4 & 3.33 & 3 & 2.41 & 2 & 1.88 & 2 & 2.29 & 4 & 2.0 \\
\hline 6. & A. versicolor & 1 & 0.83 & 2 & 1.61 & 0 & 0.00 & 2 & 2.29 & 3 & 1.5 \\
\hline 7. & A. terreus & 2 & 1.66 & 3 & 2.41 & 2 & \begin{tabular}{|l|}
1.88 \\
\end{tabular} & 0 & 0.00 & 3 & 1.5 \\
\hline 8. & A. fumigatus & 0 & 0.00 & 2 & 1.61 & 1 & \begin{tabular}{|l|}
0.94 \\
\end{tabular} & 1 & \begin{tabular}{|l|}
1.14 \\
\end{tabular} & 2 & 1.0 \\
\hline 9. & A. nidulans & 0 & 0.00 & 2 & 1.61 & 0 & 0.00 & 0 & 0.00 & 1 & 0.5 \\
\hline 10. & A. ungis & 1 & 0.83 & 0 & 0.00 & 0 & 0.00 & 2 & 2.29 & 3 & 1.5 \\
\hline 11. & A. ustus & 0 & 0.00 & 0 & 0.00 & 1 & \begin{tabular}{|l|}
0.94 \\
\end{tabular} & 0 & 0.00 & 3 & 1.5 \\
\hline 12. & A. sydowii & 1 & 0.83 & 1 & 0.80 & 1 & \begin{tabular}{|l|}
0.94 \\
\end{tabular} & 1 & $\begin{array}{ll}1.14 \\
\end{array}$ & 1 & 0.5 \\
\hline 13. & $\begin{array}{l}\text { Ascochyta } \\
\text { graminicola }\end{array}$ & 2 & 1.66 & 1 & 0.80 & 2 & 1.88 & 1 & 1.14 & 2 & 1.0 \\
\hline 14. & A. rabieii & 2 & 1.66 & 1 & 0.80 & 1 & 0.94 & 2 & 2.29 & 3 & 1.5 \\
\hline 15. & $\begin{array}{l}\text { Beauveria } \\
\text { bassiana }\end{array}$ & 2 & 1.66 & 2 & 1.61 & 2 & 1.88 & 2 & 2.29 & 2 & 1.0 \\
\hline 16. & $\begin{array}{l}\text { Cladosporiu } \\
\text { m lunata }\end{array}$ & 1 & 0.83 & 2 & 1.61 & 1 & 0.94 & 1 & 1.14 & 5 & 2.5 \\
\hline 17. & $\begin{array}{l}C . \\
\text { oxysporum }\end{array}$ & 2 & 1.66 & 2 & 1.61 & 2 & 1.88 & 2 & 2.29 & 5 & 2.5 \\
\hline 18. & C. herbarum & 1 & 0.83 & 1 & 0.80 & 2 & 1.88 & 0 & 0.00 & 1 & 0.5 \\
\hline 19. & C. elatum & 1 & 0.83 & 2 & 1.61 & 3 & 2.83 & 2 & 2.29 & 2 & 1.0 \\
\hline 20. & $\begin{array}{l}\text { C. } \\
\text { cladosporoid } \\
\text { es }\end{array}$ & 2 & 1.66 & 2 & 1.61 & 2 & 1.88 & 3 & 3.44 & 2 & 1.0 \\
\hline 21. & $\begin{array}{l}\text { Curvularia } \\
\text { lunata }\end{array}$ & 3 & 2.5 & 2 & 1.61 & 1 & 0.94 & 1 & 1.14 & 4 & 2.0 \\
\hline 22. & C. harveyi & 0 & 0.00 & 2 & 1.61 & 3 & 2.83 & 0 & \begin{tabular}{|l|}
0.00 \\
\end{tabular} & 2 & 1.0 \\
\hline 23. & C. trifoli & 0 & 0.00 & 3 & 2.41 & 2 & 1.88 & 0 & 0.00 & 3 & 1.5 \\
\hline 24. & C. borreriae & 3 & 2.5 & 1 & 0.80 & 1 & 0.94 & 2 & 2.29 & 2 & 1.0 \\
\hline 25. & $\begin{array}{l}C . \\
\text { verruculosa }\end{array}$ & 2 & 1.66 & 3 & 2.41 & 1 & 0.94 & 0 & 0.00 & 0 & 0.0 \\
\hline 26. & $\begin{array}{l}\text { Fusarium } \\
\text { oxysporium }\end{array}$ & 2 & 1.66 & 3 & 2.41 & 2 & 1.88 & 3 & 3.44 & 5 & 2.5 \\
\hline 27. & $\begin{array}{l}F . \\
\text { moliniform }\end{array}$ & 2 & 1.66 & 2 & 1.61 & 1 & 0.94 & 1 & 1.14 & 4 & 2.0 \\
\hline 28. & F. solani & 3 & 2.5 & 3 & 2.41 & 0 & \begin{tabular}{|l|}
0.00 \\
\end{tabular} & 1 & \begin{tabular}{|l|}
1.14 \\
\end{tabular} & 2 & 1.0 \\
\hline
\end{tabular}




\begin{tabular}{|c|c|c|c|c|c|c|c|c|c|c|c|}
\hline 29. & F. dimerum & 0 & 0,00 & 1 & 0.80 & 1 & 0.94 & 1 & 1.14 & 1 & 0.5 \\
\hline 30. & Fusarium Sp. & 2 & 1.66 & 2 & 1.61 & 1 & 0.94 & 1 & 1.14 & 5 & 2.5 \\
\hline 31. & $\begin{array}{l}\text { Gigaspora } \\
\text { gigentium }\end{array}$ & 2 & 1.66 & 0 & 0.00 & 1 & 0.94 & 1 & 1.14 & 3 & 1.5 \\
\hline 32. & \begin{tabular}{|l|} 
Gigaspora \\
remisporoph \\
or \\
\end{tabular} & 1 & 0.00 & 4 & 3.22 & 1 & 0.94 & 3 & 3.44 & 2 & 1.0 \\
\hline 33. & \begin{tabular}{|l}
$\begin{array}{l}\text { Glomus } \\
\text { mosseae }\end{array}$ \\
\end{tabular} & 2 & 1.66 & 2 & 1.61 & 3 & 2.83 & 0 & 0.00 & 4 & 2.0 \\
\hline 34. & \begin{tabular}{|l|}
$G$. \\
ambisporum
\end{tabular} & 1 & 0.00 & 2 & 1.61 & 4 & 3.77 & 0 & 0.00 & 2 & 1.0 \\
\hline 35. & $\begin{array}{l}\text { G.formosanu } \\
m\end{array}$ & 3 & 2.5 & 1 & 0.80 & 2 & 1.88 & 1 & 1.14 & 2 & 1.0 \\
\hline 36. & Gleosporium & 1 & 0.00 & 0 & 0.00 & 1 & 0.94 & 2 & 2.29 & 5 & 2.5 \\
\hline 37. & \begin{tabular}{|l|}
$\begin{array}{l}\text { Humicola } \\
\text { grisea }\end{array}$ \\
\end{tabular} & 2 & 1.66 & 1 & 0.80 & 3 & 2.83 & 1 & 1.14 & 2 & 1.0 \\
\hline 38. & Unidentified & 0 & 0.00 & 3 & 2.41 & 1 & 0.94 & 0 & 0.00 & 4 & 2.0 \\
\hline 39. & \begin{tabular}{|l} 
Lasidiobolust \\
heobramae
\end{tabular} & 2 & 1.66 & 1 & 0.80 & 2 & 1.88 & 1 & 1.14 & 2 & 1.0 \\
\hline 40. & Mucorsp. & 1 & 0.00 & 2 & 1.61 & 3 & 2.83 & 1 & 1.14 & 3 & 1.5 \\
\hline 41. & M. mucido & 1 & 0.00 & 2 & 1.61 & 2 & 1.88 & 2 & 2.29 & 3 & 1.5 \\
\hline 42. & M. hiemallis & 1 & 0.00 & 2 & 1.61 & 1 & 0.94 & 1 & 1.14 & 1 & 0.5 \\
\hline 43. & $\begin{array}{l}\text { Macrophomi } \\
\text { na } \\
\text { phaseolina } \\
\end{array}$ & 1 & 0.00 & 2 & 1.61 & 1 & 0.94 & 2 & 2.29 & 4 & 2.0 \\
\hline 44. & $\begin{array}{l}\begin{array}{l}\text { Metarhizium } \\
\text { anisopliae }\end{array} \\
\end{array}$ & 2 & 1.66 & 1 & 0.80 & 0 & 0.00 & 2 & 2.29 & 4 & 2.0 \\
\hline 45. & $\begin{array}{l}\text { Nigrospora } \\
\text { oryzae }\end{array}$ & 2 & 1.66 & 2 & 1.61 & 4 & 3.77 & 3 & 3.44 & 2 & 1.0 \\
\hline 46. & $\begin{array}{l}\text { Neocosmosp } \\
\text { ora sp. }\end{array}$ & 1 & 0.00 & 4 & 3.22 & 0 & 0.00 & 1 & 1.14 & 3 & 1.5 \\
\hline 47. & $\begin{array}{l}\text { Penicillium } \\
\text { rubrum }\end{array}$ & 1 & 0.00 & 2 & 1.61 & 3 & 2.83 & 2 & 2.29 & 5 & 2.5 \\
\hline 48. & P. tardum & 1 & 0.00 & 1 & 0.80 & 0 & 0,00 & 1 & 1.14 & 2 & 1.0 \\
\hline 49. & P. citrinum & 0 & 0.00 & 2 & 1.61 & 1 & 0.94 & 2 & 2.29 & 4 & 2.0 \\
\hline 50. & \begin{tabular}{|l|}
$P$. \\
purprogenum
\end{tabular} & 1 & 0.00 & 0 & 0.00 & 0 & 0.00 & 0 & 0.00 & 1 & 0.5 \\
\hline 51. & $\begin{array}{l}P . \\
\text { puberrulum }\end{array}$ & 1 & 0.00 & 1 & 0.80 & 1 & 0.94 & 1 & 1.14 & 2 & 1.0 \\
\hline 52. & \begin{tabular}{|l|} 
Phoma \\
nebulosa
\end{tabular} & 2 & 1.66 & 1 & 0.80 & 2 & 1.88 & 1 & 1.14 & 4 & 2.0 \\
\hline 53. & P. humicola & 1 & 0.00 & 2 & 1.61 & 1 & 0.94 & 1 & 1.14 & 4 & 2.0 \\
\hline 54. & P. terricola & 3 & 2.5 & 1 & 0.80 & 1 & 0.94 & 0 & 0.00 & 3 & 1.5 \\
\hline 55. & $\begin{array}{l}\text { Phycomyses } \\
\text { Sp. }\end{array}$ & 2 & 1.66 & 1 & 0.80 & 1 & 0.94 & 2 & 2.29 & 2 & 1.0 \\
\hline 56. & \begin{tabular}{|l} 
Rhizopus \\
oryzae
\end{tabular} & 2 & 1.66 & 1 & 0.80 & 1 & 0.94 & 1 & 1.14 & 2 & 1.0 \\
\hline 57. & R. arrhizus & 2 & 1.66 & 1 & 0.80 & 0 & 0.00 & 1 & 114 & 1 & 0.5 \\
\hline 58. & $\begin{array}{l}\text { Sclerotium } \\
\text { oryzae }\end{array}$ & 1 & 0.00 & 1 & 0.80 & 1 & 0.94 & 2 & 2.29 & 2 & 1.0 \\
\hline 59. & $\begin{array}{l}\text { Unidentified } \\
\text { (yeast) }\end{array}$ & 2 & 1.66 & 0 & 0.00 & 2 & 1.88 & 1 & 1.14 & 4 & 2.0 \\
\hline
\end{tabular}




\begin{tabular}{|c|c|c|c|c|c|c|c|c|c|c|c|}
\hline 60. & $\begin{array}{l}\text { Scutellospora } \\
\text { pellucid }\end{array}$ & 1 & 0.00 & 2 & 1.61 & 0 & 0.94 & 1 & 1.14 & 3 & 1.5 \\
\hline 61. & S. gregarea & 2 & 1.66 & 2 & 1.61 & 1 & 0.94 & 1 & 1.14 & 2 & 1.0 \\
\hline 62. & $\begin{array}{l}\text { Sphaeronema } \\
\text { sp. }\end{array}$ & 1 & 0.00 & 1 & 0.80 & 1 & 0.94 & 2 & 2.29 & 3 & 1.5 \\
\hline 63. & $\begin{array}{l}\text { Trichoderma } \\
\text { viride }\end{array}$ & 8 & 6.66 & 5 & 4.03 & 6 & 5.66 & 3 & 3.44 & 4 & 2.0 \\
\hline 64. & T. harzianum & 3 & 2.5 & 4 & 3.22 & 4 & 3.77 & 2 & 2.29 & 5 & 2.5 \\
\hline 65. & T. lignorum & 2 & 1.66 & 1 & 0.80 & 2 & 1.88 & 0 & 0.00 & 4 & 2.0 \\
\hline 66. & $\begin{array}{l}\text { Verticillium } \\
\text { Sp. }\end{array}$ & 1 & 0.00 & 2 & 1.61 & 0 & 0.00 & 2 & 2.29 & 2 & 1.0 \\
\hline 67. & $\begin{array}{l}\text { Candida } \\
\text { famata }\end{array}$ & 3 & 2.5 & 1 & 0.80 & 0 & 0.00 & 2 & 2.29 & 2 & 1.0 \\
\hline 68. & $\begin{array}{l}\text { Rhodotorula } \\
\text { Sp. }\end{array}$ & 2 & 1.66 & 2 & 1.61 & 2 & 1.88 & 0 & 0.00 & 3 & 1.5 \\
\hline 69. & $\begin{array}{l}\text { Debaryomyc } \\
\text { es Sp. }\end{array}$ & 3 & 2.5 & 0 & 0.00 & 1 & 0.94 & 3 & 3.44 & 5 & 2.5 \\
\hline \multicolumn{2}{|c|}{ Total colony } & & 121 & & 123 & & 106 & & 87 & & 126 \\
\hline
\end{tabular}

Table.2 Diversity analysis of microfungi including yeasts in three different ecosystems -Agriculture,

Barren and Garden land and their comparison

\begin{tabular}{|l|l|l|l|l|l|l|}
\hline $\begin{array}{l}\text { Soil } \\
\text { type(Ecosystem } \\
\text { type) }\end{array}$ & $\begin{array}{l}\text { No. of } \\
\text { Samples } \\
\text { collected }\end{array}$ & $\begin{array}{l}\text { Total } \\
\text { no. of } \\
\text { colonies } \\
\text { isolated }\end{array}$ & $\begin{array}{l}\text { Average } \\
\text { No. of } \\
\text { colonies } \\
\text { isolated }\end{array}$ & $\begin{array}{l}\text { No. of } \\
\text { identified } \\
\text { genera }\end{array}$ & $\begin{array}{l}\text { No. of } \\
\text { identified } \\
\text { Species }\end{array}$ & $\begin{array}{l}\text { Simpson's } \\
\text { Diversity index } \\
\text { 'D' }\end{array}$ \\
\hline Agriculture land & 20 & 350 & 17.5 & 31 & 67 & 0.6139 \\
\hline Barren land & 08 & 87 & 10.87 & 28 & 54 & 0.9763 \\
\hline Garden land & 10 & 126 & 12.6 & 30 & 66 & 0.950 \\
\hline Total & 38 & 563 & 40.97 & 89 & 187 & ---- \\
\hline
\end{tabular}

Fig.1 Map of the Khardah Municipality

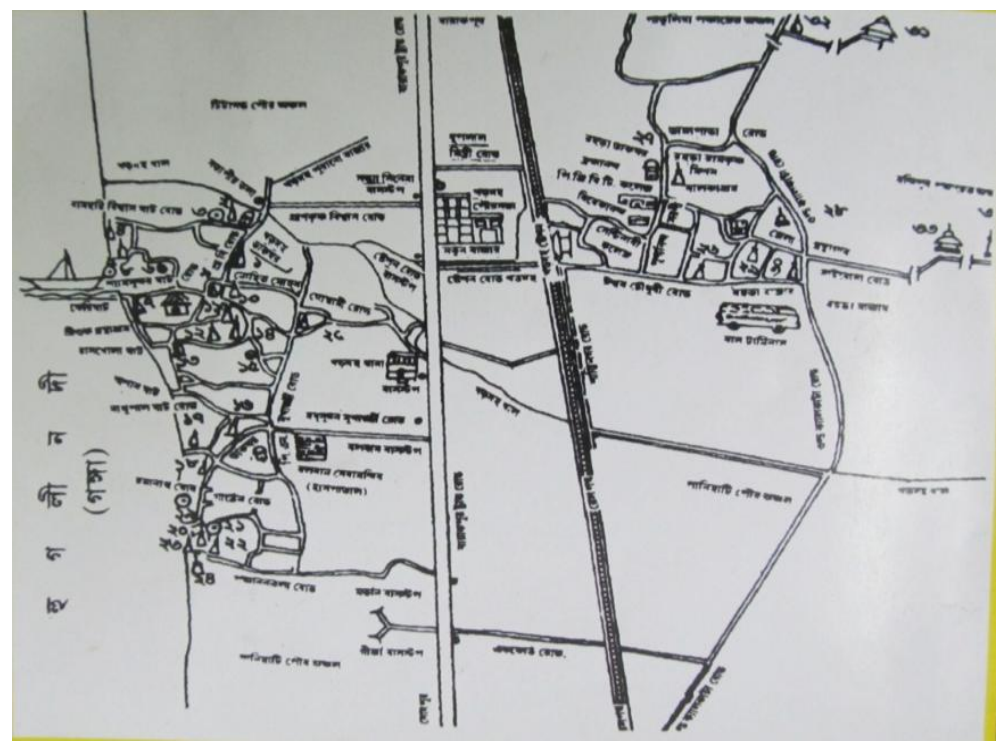


Although here other factors of soil such as the soil $\mathrm{pH}$, organic content and water are not taken, but these factors affecting the fungal population and diversity (Yu et al., 2007). Isolation and Identification of soil mycoflora from different Populated Area of Bareilly City were done by Kumar, et al., (2015). During the investigation period 161 fungal colonies of 8 fungal species were observed (Kumar, et al., 2015). They recorded that the maximum fungal species belongs to Ascomycotina and Zygomycotina were observed. In their findings, Aspergillus niger (13.04\%), Aspergillus flavus (13.04\%), Aspergillus fumigates (13.6\%), Aspergillus terrus (10.5\%), Aspergillus fumigates (13.6\%), Aspergillus niger (13.04\%), Aspergillus flavus (13.04\%), Aspergillus terrus (10.5\%) were the dominant species, and other few of them were Aspergillus nidulance (9.3\%), Botrytis cineria (5.59\%), Rhizopus oryzae (8.07\%), and Trichoderma viride $(8.07 \%)$ were found in their respective percentage. In this experiment the diversity of soil fungi have same trends. The diversity of yeasts in different natural resources including fruits in 24-Parganas, West Bengal were analysed by us (Ghosh et. al. 2013, 2015). Moreover, we (Pal and Ghosh 2015) have recorded the diversity of fungi in agricultural fields and gardens in North 24 Parganas, West Bengal. Out of thirty-one fungal species isolated with 19 found in agricultural soil and 28 in garden soil. In agricultural soil, the dominant fungi were Aspergillus niger, Rhizopus oryzae, and Penicillium expansum, and the dominant fungi of garden soil were A. niger and Fusarium moniliforme. Simpson's diversity index indicated that garden soil had more fungal diversity than agricultural soil (Pal and Ghosh 2015). But in this experiment diversity of fungi in agricultural soil is higher than garden soil; it may indicate that farmers of Khardah and adjoining applied less fungicide in comparison to agrisoil of the whole district of 24-Parganas (N) keeping the soil health good.

\section{References}

Alabouvette, C., Couteadier, Y. 1992. Biological Control of Plant Diseases: Progress and Challenges for the Future. In: Biological Control of Plant Diseases, Tjamos, E.C.,
G.C. Papavizas and R.J. Cook. Eds. Plenum Press, New York. pp: 415-426.

Barnet, J.A., Payne, R.W., Yarrow, D. 2000. Yeasts characteristics and identification, 3rd edn. Cambridge University Press.

Barnett, H., Hunter Leslie., Barry B. 1998. Illustrated Genera of Imperfect Fungi 4th (fourth) Edition, Amer Phytopathological Society.

Dhingra, O.D., Sinclair, J.B. 1986. Basic plant pathology Methods CRC Press, Inc.

Domsch, K.H., Gams, W., Anderso, T.H. 1980. Compendium of soil Fungi Vol. I \& II, Academic Press London.

Dox, 1910. The intracellular enzymes of Penicillium and Aspergillus with special reference to those of $P$. camemberti. US Department of Agriculture Bureau Animal India Bull, 120, 170

Eckert, J.W., Ogawa, J.M. 1988. The chemical control of postharvest diseases: Deciduous fruits, berries, vegetables and root/tuber crops. Ann. Rev. Phytopathol., 26: 433-446.

Finlay, R.D., 2007. The fungi in soil, pp. 107146.In J.D. Van Elsas, J.K. Jansson and J.T. Gilman, J.C. (2001): A Manual of Soil fungi. 2nd Indian edition, Biotech Books, Delhi.

Ghosh, S.K., Santra, T., Chakravarty, A. 2015.Study of Yeast Flora of Fruits and Their in Vitro Screening for Antagonistic Property Against Penicillium Digitatum International Journal of Scientific Research 4(7): 410-413.

Ghosh, S.K., Santra, T., Chakravarty. A. 2013. Study of antagonistic yeasts isolated from some natural sources of West Bengal Agric. Biol. J. N. Am., 201 3, 4(1): 33-40.

Harrison, I., Laverty, M.D., Sterling, E. 2004. Species diversity, version 1(3): Jul 29, (http://cnx.org/content/m12174/1.3).

Kumar, V., Yadav, U., Kumar, A. 2015. Isolation and Identification of Soil Mycoflora from Different Populated Area of Bareilly City. Bull. Env. Pharmacol. Life Sci., 4(7): 151156

Kurtzman, C.P., Fell, J.W., Boekhout, T. 2012. The yeasts - a taxonomic study, 5th Ed. North Holland, Amsterdam.

Mustaq, M.S., Nahar, M. H., Hashmi. 2004. Isolation and identification of yeast flora 
from soil of Karachi, Pakistan. Pak. J. Bot., 36(1), 173-180.

Nagamani, A., Kunwar, I. K. Manoharachary, C. 2006. Hand book of Soil Fungi. I. K. International, New Delhi, 477.

Pal, S., Ghosh, S.K. 2015. Diversity of soil fungi in North 24 Parganas and their antagonistic potential against Leucinodes orbonalis Guen. (Shoot and fruit borer of brinjal) Environ Monit Assess 186:8707-8716.

PAN, 2007. http:// www.paninternational.org/ panit/file/WG1/Eliminating the worst pesticide.pdf

Ponmurugan, P., Baby, U.I. 2003. In vitro interaction of fungal antagonists with Phomopsis theae, the causal agent of collar canker disease in tea. Indian J. Microbiol., $43,41-44$.

Powler, D., 2006. "Blue baby links - 11 February 2006 - New Scientist". Retrieved 2008-0324.

Primaves, I.A., PrimavesI, A.M. 1990. Soil life and chemical fertilizers ILEIA Newsletter 6 no 3 October 1990(www.agriculturenet.org)

Ross, A., Harrisson, J.S. 1987-1993. The Yeast Vol. 1-5 Academic Press, London.

Sanchez, P.A., Swaminathan, M. S. 2005. Hunger in Africa: the link between unhealthy people and unhealthy soils. Lancet. 365: $442-44$

Saravnakumar, K, Kaviyarasan, V. 2010. Seasonal distribution of soil fungi and chemical properties of montane wet temperature forest types of Tamil Nadu. African Journal of plant Science. 4(6): 190- 196.

Schimel, J.P., Bennett, J., Fierer, N. 2005. Microbial community composition and soil nitrogen cycling: is there really a connection? p. 172-188. In R.D. Bardgett, M.B. Usher, and D.W. Hopkins (eds.) Biological diversity and function in soils. Cambridge University Press, Cambridge, UK.

Smith, P., Martino, D., Cai, Z., Gwary, D.,
Janzen, H.,Kumar, P., Mc-Carl, B., Ogle, S., O'Mara, F., Rice,C., Scholes,.B, Sirotenko, O., Howden, M.,McAllister, T., Pan, G., Romanenkov, V., Schbeider U, Towprayoon S, Wattenbach M, Smith J. 2008. Greenhouse gas mitigation in agriculture. Philosophical Transaction of the Royal Society, 363: 789-813.

Subramanian, C.V., 1971. Hyphomycetes, ICAR, New Delhi, pp. 930.

Subramanian, C.V., 2007. The biodiversity agenda: emerging trends in taxonomy. In World Fungi: 1. Taxonomy, pp.119-121

Tedersoo, L., Bahram, M., Polme S., Kõljalg U., Nourou S. Y., 2014 Global diversity and geography of soil fungi. Science. 346:p.1078.

Tsao, P.H., 1964. Effect of Certain Fungal Isolation Agar Media on Thielaviopsis basicola and on its Recovery in Soil Dilution Plates. Phytopathology, 54, 548555

Wahegonkar, N., Salunkhe, S.M, Palsingankar, P.L, Shinde. S.Y. 2011. Diversity of fungi from soils of Aurangabad, M.S., India. Annals of Biological Research, 2(2): 198205

Warcup, J.H., 1950. The Soil-Plate Method for Isolation of Fungi from Soil. Nature. 166: 117-118. doi: 10.1038/166117b0.

Ward, M.H., De-Kok, T.M., Levallois, P., Brender, J., Gulis, G., Nolan, B.T., VanDerslice, J. 2005."Workgroup Report: Drinking-Water Nitrate and HealthRecent Findings and Research Needs". Environ. Health Perspectives, 113(11): 1607-1614.

Wickerham, L.J., 1951. Taxonomy of Yeasts, Technical Bulletin No.1029 United States Department of Agriculture.

Yu C., Lv. D. G., Qin S.J., Liu, G.C. 2007. Diversity analysis of soil dematiaceous hyphomycetes from the Yellow River source area. J. Appl. Ecol., Vol. 18.

\section{How to cite this article:}

Swapan Kumar Ghosh and Sur, P.K. 2017. Study of Micromycoflora and Fungal Diversity Analysis and Comparison among Three Different Ecosystems (Agricultural Land, Barren and Garden Land) of Khardah Municipality, 24 Parganas (N), West Bengal, India. Int.J.Curr.Microbiol.App.Sci. 6(9): 710719. doi: https://doi.org/10.20546/ijcmas.2017.609.087 